a method which calls to mind the methods of the tailors of Laputa.-I am, etc.,

Dista Products Ltd., Liverpool

W. H. LYLE 1 Asberg, M., et al., British Medica: fourna:, 1971,
3, 331 .
2 Kragh-Sorensen, P., Asberg, M., and Eggert-
Hansen, C., Lancet, 1973, 1, 113. Medical fournal,
3 Lyle, W. H., et al., Postgradiate Med:cal fournat,
1974, 50, 282. 1974, 50,282 .

\section{Malignant Hyperpyrexia}

SIR,-I should like to make a few comments on your leading article (30 November, p. 488 ) on malignant hyperpyrexia. Denborough and Lovell ${ }^{1}$ were the first to report a case of malignant hyperpyrexia in 1960 . They followed this with a more detailed report in $1962,2^{2}$ well before Saidman et al. in $1964 .^{3}$ However, Saidman et al. can claim to be the first to treat malignant hyperpyrexia successfully with the help of steroids. They cured a patient whose temperature had risen to $108.5^{\circ} \mathrm{F}\left(42.5^{\circ} \mathrm{C}\right)$ with an arterial $\mathrm{pH}$ of 682 , and reduced his temperature within an hour to $97.2^{\circ} \mathrm{F}\left(36.2^{\circ} \mathrm{C}\right)$ using icepacks and prednisone. ${ }^{3}$

You imply that myotonia congenita is a myopathy that commonly underlies malignant hyperpyrexia. This is not so: the association between myotonia congenita and malignant hyperpyrexia is extremely rare. Saidman's case of malignant hyperpyrexia No. 2 in his report) was described as suffering from a generalized muscle weakness diagnosed as myotonia congenita. ${ }^{3}$ However, no clinical sign of myotonia was mentioned, and muscle weakness is not a common sign of myotonia congenita. Histology at necropsy showed generalized polymyositis. Thus the diagnosis in this case is in doubt.

Harriman et al. ${ }^{4}$ reviewed patients that recovered from malignant hyperpyrexia and their relatives. The only clinical signs of myopathy that they found were hypertrophy and slight weakness of the lateral parts of the thigh and absent ankle jerks-no clinical sign of myotonia was seen nor was there any histological evidence. Certainly Britt et al. ${ }^{5}$ could find no evidence of myotonia in their investigations. . Other reports ${ }^{78}$ confirm that myotonia congenita is not usually the underlying myopathy. To put things in perspective, King et al. ${ }^{9}$ have reported one patient who developed malignant hyperpyrexia who came from a family affected by myotonia congenita. None of the other 17 patients or their relatives who were investigated were affected by myotonia congenita.

It would not be surprising if there is a small rise in temperature associated with the generalized muscle spasm that sometimes follows the administration of suxamethonium to a patient with myotonia. Cody ${ }^{10}$ described such a case in which the temperature reached $99.4^{\circ} \mathrm{F}\left(37.5^{\circ} \mathrm{C}\right)$-hardly characteristic of malignant hyperpyrexia. Reports of cases with clinical myotonia (both dystrophia myotonica and myotonia congenita) undergoing anaesthesia do not mention complicaions from pyrexia. ${ }^{11-13}$ Thus there is one report of a patient with myotonia congenita developing malignant hyperpyrexia. The evidence at present suggests that this association may be purely one of chance rather than significance.-I am, etc.,

Norfolk and Norwich Hospital.

P. FURNISS
Denborough, M. A., and Lovell, R. R. H., Lancet, $1960,2,45$.

Denborough, M. A., et al.,
Anaesthesia, 1962, 34, 395.

fournal of the American M. Hedical Eger, E. I., 1964, 190, 1029 .

Harriman, D. G. F., Sumner, D. W., and Ellis, F. R., Quarterly fournal of Medicine, 1973, 42, 639 .

Canadian A., Locher, W. W., and Kalow, W. W.,

Barlow, H., and Isaacs, M. B., British fourral of Anaesthesia, 1970, 42, 1072.

A 15, 299.

8 Steers, A. J. W., Tallack, J. A., and Thompson, D. E. A., British Medical Fournal, 1970, 2, 341. King, J. O., Denborough, M. A., and Zapf, P. Lancet, 1972, 1, 365.

Cody, J. R., Anesthesiology, 1968, 29, 159. Kaufman, L., Proceedings of the Royal Society of

Aclelland. R. M. A., British fournal of Anaesthesia, 1960, 32. 81 .

39, 815 .

\section{Diagnostic Test for Multiple Sclerosis}

SIR,-In refuting the specificity of the linoleic acid test for multiple sclerosis, ${ }^{1}$ Mertin et al." maintain that they have repeated the work "under conditions which were not . . . changed in any material respect." While it is true that one of us (B.K.S.) made the measurements upon which their paper is based, there were important differences.

(1) Absence of E.J.F. with his personal supervision of the animal supply.

(2) Failure of adequate checking for guinea-pig sensitization during the relevant November-December period. A major part of the trial was carried out during (influenzaridden) December-when only one check was made. Indeed, Mertin et al.'s pretty, but largely irrelevant, fig. 2 serves mainly to show how ohecking lapsed after June, when E.J.F. relinquished control. Unfortunately, Professor A. M. Thomson was not able to give the time at which animal house precautions $^{3}$ were allowed to lapse, though the need for them had long been known to Mr. E. A. Caspary. ${ }^{\prime}$

(3) The finding of occasional spontaneous sensitization to P.P.D. in concomitant macrophage migration inhibition tests carried out by Mr. D. Hughes ${ }^{3}$ on the stock of normal guinea-pigs used as the source of normal macrophages. This direct experimental evidence of presensitization, vital in the present context, is omitted from Mertin et al.'s presentation. Successful operation of the macrophage electrophoretic mobility (M.E.M.) test requires the use not only of Analar grade chemical reagents but also of a similar grade of the most complicated reagent of all, the macrophage cell.

(4) Use of P.P.D. as test antigen in place of thyroid ${ }^{1}-a$ substitution without importance if non-sensitized guinea-pigs are used as the source of macrophages but one which experimental test shows to lead to bizarre results if animals are presensitized. ${ }^{5}$

Mertin et al., in quoting Shenton, ${ }^{3}$ stop short of reference to "certain other sources of error which may have been operating."3 For example, Professor Thomson was unable to give an assurance that detergents had not been reintroduced into the glassware cleaning process. This too may lead to random results (including those from duplicate specimens). A recent test carried out in another laboratory showed that merely drawing macrophages five or six times through a Decon-cleaned pipette- perfectly adequate for other purposes-added one second to the migration time of the cells.

In experiments involving the M.E.M. test specimens have from the very beginning been randomized and presented to the observer in numbered bijou bottles ${ }^{6} 7$ so that it would require a paranormal feat of some magnitude on the part of B.K.S. to know upon which specimens to bring to bear his "subjective bias." In many family studies he did not, in fact, know which was the multiple sclerosis patient.

The consistency of the method is attested by the series of control figures published by Mr. Caspary ${ }^{7}$ and by Shenton et al. ${ }^{8}$ The latter (Mr. Hughes being a coauthor) have eliminated some of the "subjective element" in the measurements. For each result the statistical significance has been calculated (from the raw data) and with present expertise (B.K.S.) percentage differences as low as $7-8 \%$ correspond to a $\mathrm{P}$ value of $<0.01$ (as opposed to the $15 \%$ needed two or three years ago). Increasing accuracy has also been a feature of Mr. Caspary's own later results. Finally, the result of just such a "doubleblind" trial advocated by Mertin et al., in which the observer does not know the provenance of the bloods from which his scrambled numbered bottles have been prepared, was published by Jenssen et al. ${ }^{9}$ on the same day as Mertin's denial. In a first series they clearly differentiated multiple sclerosis patients on the one hand from patients with other neurological diseases and normal subjects on the other. With increasing experience they reported (in a second series $^{9}$ ) figures almost identical with those of Field et al. ${ }^{1}-\mathrm{a}$ clear encouragement to those prepared to exercise the attention to detail that the method demands. It might be added that these authors had previously confirmed the cancer test ${ }^{11}$ greeted (not unnaturally) with so much scepticism when it first appeared but now substantiated in several laboratories. ${ }^{12}$ - We are, etc.

E. J. FIELD

B. K. SHenton

Department of Pathology,
Newcastle General Hospital,

1 Field, E. I., Shenton, B. K.. and Joyce, G., Fritish Medical fournal, 1974, 1, and Joyce, G.,

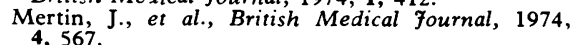
3 Shenton, B. K., and Caspary, E. A., Lancet,

1972, 1, 963.

Field, E. J., and Caspary, E. A., Lancet, 1970, Caspary, E. A., and
fournal, 1971, 2, 613 Briton, B. K., Hughes, D., and Field, E. J., 215 .

9 Jensen, H. L., et al., Lancet, 1974. 2, 1327

10 Jenssen, H. L., et al., British Medical fournal, 1974, 4, 407. Meyer-Rienecker, H.,
schrift, 1974, 52, 288.

12 Nature, $1973,244,130$.

\section{Pericarditis and Peritonitis Associated with} Practolol Therapy

SIR,-There have been increasing reports of side effects of practolol, including pericarditis and "sclerosing or plastic peritonitis." The following case may represent another of these unusual reactions.

A 48-year-old man was seen in February 1973. He had had palpitations for eight 